\title{
Research and Practice of Practice Teaching Content System of Garment Design and Engineering
}

\author{
Shuimei Liu $^{1}$ \\ ${ }^{1}$ Jiangxi Institute of Fashion Technology, Nanchang Jiangxi, China, 330201
}

KEYWORDS: Garment Design and Engineering, Practice Teaching, Practical talents

\begin{abstract}
Fashion Design and Engineering is to train as a social practical personnel should master the basic theory of clothing discipline, with solid engineering and technical knowledge, a high cultural quality and aesthetic ability. Practice teaching is the inevitable requirement of Garment Design and Engineering Specialty Training Comprehensive talents, but are currently a fashion design and engineering practice courses of universities there are many problems, can not meet the apparel industry demand for integrated talent, so the construction and improvement of practice Teaching system is the perfect fashion design and engineering teaching objectives inevitable requirement. In this paper, the present time teaching costume design and engineering analyzes, and then describes the characteristics of the professional practice of teaching and goals on this basis, from three aspects content system, hardware facilities and management practice teaching system proposed suggestions and measures to improve the payment design and engineering practical teaching system and training of qualified personnel for composite applications to meet the needs for talents.
\end{abstract}

\section{Introduction}

Integrated application-oriented talents is China's rapid economic development process of the basic requirements for personnel, modern teaching colleges and universities is to cultivate high-quality personnel, should pay attention to practice teaching, cultivate students 'creative and practical ability to develop and enhance students' potential overall quality. With the rapid development of China's garment industry, the requirements of China's garment education reform should also be strong, to do with international standards, training applications, skilled, complex senior technical personnel clothing. Costume design and engineering practice teaching profession can effectively improve students' practical skills, so analyze and solve problems, higher input management personnel, technical personnel, creative talent and reserve personnel for the society. Fashion Design and Engineering Colleges should increase our innovative practice teaching system, in-depth reform, to explore a new road for the practical teaching professional, qualified people to enter the community, cultivate outstanding talents clothing.

\section{The Shortcomings of Practice Teaching Education of Costume Design and Engineering Profession}

At present, China is now a big country clothing industry, domestic and foreign clothing big gathering, all enterprises, brand formed a huge industrial chain. China has a strong consumer market and abundant labor, the development of the apparel industry has a huge and prominent industrial advantages. College teaching practice is the interface between education and apparel 
market as a bridge, so that students can quickly understand the market and adapt to the market, reform and innovation of Fashion Design and Engineering Practice Teaching System is the University of Applied Talents necessary way. Now present, China's fashion design and engineering has been gradually realized the importance of practice teaching, with better school labs and campus practice base, to carry out school - enterprise cooperative manner, provide more practice opportunities for students to obtain some results. But now the time for further analysis current status of teaching in Chinese universities fashion design and engineering, there are many shortcomings, which are a serious impediment to the healthy development of China's garment industry.

Practical teaching and basic theoretical knowledge divorced from China's garment industry is now currently a common phenomenon in talent cultivation, a serious impediment to the healthy development of the profession. Between costume design and engineering teaching content independent of each other, the link between the individual is not strong. And China's garment design and engineering professional teaching content updates more slowly, seriously behind developed countries. Costume design and engineering university teaching center of gravity on the basis of theory, not practice-oriented teaching, teaching and did not practice and theoretical knowledge on the same height, are generally once or twice a week practice teaching, and no vacation arrange internships. Lack of ability so that students can not meet the needs of the community. Poor teaching practice systematic practice of teaching is mainly to serve the teaching of theoretical knowledge, practical teaching system does not form a unique, practical content scattered, the lack of specific, there has been the phenomenon of touch with social needs.

Now currently, costume design and engineering of universities and businesses have been signed, although the relevant internship employment contracts, increased personnel training and delivery efforts, but still many deficiencies exist. Such as vacation and did not do internships mandatory requirements, mostly voluntary, and lower management, some students did not get the corresponding practice exercise. Holidays also provides internship is basically left on the hands-on level, rarely involved in enterprise technology research and development, students' practical ability is weak. Enterprises do not pay attention to students 'pre-practice teaching, the school does not focus on practical ability of students, teachers' professional focus is still on the theory of teaching, most of the skills training courses is perfunctory.

\section{The Features and Objectives of Fashion Design and Engineering Practice Teaching}

Fashion Design and Engineering is an artistic creation and industrial production of a combination of educational discipline, the profession of teaching not only to comply with the general clothing professional teaching requirements, but also pay attention to and highlight the practical teaching, the arts disciplines and engineering disciplines organically together.

Fashion Design and Engineering Practice Teaching Objectives Key primarily the basic theoretical knowledge and practical operation of the organic combine, combining traditional basic theory, complete distinctive practice teaching content, so that the practice of teaching to become clothing design and engineering teaching content Important part, gradually formed the core of capacity-building, integrated, multi-level, open new practice teaching system.

\section{Construction of Fashion Design and Engineering Practice Teaching System}

School is the main clothing design and engineering practice teaching. Major colleges and universities should be teaching costume design and engineering fundamentals-based education, strengthen the practice of teaching. Schools should pay attention to the students' practical teaching, 
so that education and international clothing standards, actively update teaching content. Various education departments and institutions of the country should increase investment in infrastructure of schools teaching practice, complete the facilities. In terms of setting school class, to strengthen the basic theory of foreign culture of students, should enhance the practice of teaching hours, enhance students 'practical ability, so that theory and knowledge to effectively combine the development of students' creative ability. Now at present, Chinese universities costume design and engineering time teacher teaching ability is generally insufficient, mostly amateur, did not undergo specialized training, the school should increase the practice of teacher training courses, improve teaching ability. In the teaching process, we should actively use a variety of modern teaching facilities, improve teaching methods and improve practice programs to develop integrated application garment talents.

Enterprises should be actively carried out extensive cooperation and schools to provide students with more practice teaching resources. Enterprise is the ultimate attribution costume design and engineering professionals, only the importance of early and strengthening personnel training, to be able to do the job better. School contract signed between the enterprise and the establishment of off-campus practice base, establish long-term cooperation. During the four years of school culture, companies should provide students with the opportunity to practice a large number of short-term, strengthen management, to properly expose students to some of the core of the company's work to create more opportunities for hands-on practice of students. Training campus practice ability, not only to improve their practical ability, but also to increase the students' social experience, to lay a good foundation for graduate work, quickly adapt to the work environment.

Now present, at home and abroad have been many standard innovative design competition, the school should actively encourage their participation. Carried out between the government, schools, businesses three extensive cooperation, carry out component design competition, set a certain reward. During the undergraduate students' overall research capacity is low, school teachers should encourage students to drive to improve research, develop their creativity, the creation of an effective combination of research and teaching, the Innovative Design Competition and Practice combined. Schools should encourage students to participate in international fashion design and engineering of the game, the game instantly provide relevant news for them, and to improve their professional practice skills, broaden their horizons, not to rest on its laurels, follow the international fashion apparel.

\section{Conclusion}

Practice teaching colleges and universities train high quality applied talents indispensable content. Teaching basic theoretical knowledge, practical operation better able to cultivate students' creative ability and compared to ability, overall quality of training personnel to meet the needs of society, it should increase the garment design and engineering home practice teaching system innovation, the school culture and school Training together organically, encourage students to actively participate in a variety of scientific research competition, improve the comprehensive ability.

\section{References}

[1] Zou Ping. Research and Practice Garment Design and Engineering Specialty Practice Teaching Content System [J]. Progress in Textile Science and Technology, 2009, (5): 95-97.Construction

[2] Zhu Fanglong. Garment Design and Engineering Specialty Practice Teaching System [J]. textile and apparel education, 2012,27 (6): 490-493.

[3] Wang Lijun. SCI-Tang Jiefang research experiment teaching system for the cultivation of 
creative ability and costume design and engineering practice [J]. Experimental Technology and Management, 2012,29 (8): 133-136.

[4] Zhou Jing. College fashion design innovative teaching methods - effective combination of theory and practice [J]. China (HEAD), 2012, (4): 36. 